\title{
Influence of Training Levels of Private Security Service Providers in Crime Prevention in Lurambi Sub-County, Kenya
}

\author{
Dr. Evans M. Oruta \\ Lecturer, Department of Criminology and Social Work, Masinde Muliro University of Science and Technology \\ P.O Box 190 - 50100, KAKAMEGA, KENYA \\ Ahmed Kassim Wangara \\ Department of Criminology and Social Work, Masinde Muliro University of Science and Technology \\ P.O Box 190 - 50100, KAKAMEGA, KENYA
}

\begin{abstract}
This study aimed to examine the role of private security providers in crime prevention in Lurambi Sub-County, Kenya. The study was necessitated by private security providers' presence and use to protect life, property, and maintenance of law and order in Lurambi Sub-County, Kakamega County, Kenya. The Routine Activity and Situational Crime Prevention Theories of criminology informed the study. Specifically, this study intended to establish resource availability for private security service providers in crime prevention in Lurambi Sub-county, Kenya. The study adopted descriptive and correlational research designs. The primary target population constituted 358 respondents, both male and female, drawn from six registered and regulated private security service providers in Lurambi Sub-County, 5 senior police officers in charge of security, police administration, and 4 police stations across Lurambi Sub-County, and 133 clients of private security services. Purposive sampling was used to identify the 6 registered and licensed private security firms which provided the study population. Proportionate sampling with a statistical framework of $30 \%$ was used to identify 108 private security service providers who formed the sample size to ensure that the private security officers from the 6 firms were represented in the same proportion that they existed within the population. Questionnaires were used to collect data from three groups of respondents, including 108 private security officers, 6 managers each in charge of each private security firm that participated in the study, and 40 clients sampled from the 6 private security firms that participated in the study. Interview guides were used to collect data from 5 senior police officers in charge of security, police administration, and 4 police stations spread across Lurambi Sub-County. The study findings revealed that private security service providers were not adequately trained, hence impacting crime prevention negatively in Lurambi Sub-County. The study recommended that private security service providers consider providing relevant and timely training programs to strengthen crime prevention efforts.
\end{abstract}

Key Terms: Training Levels, Private Security, Crime Prevention

DOI: $10.7176 /$ PPAR/11-6-04

Publication date:July $31^{\text {st }} 2021$

\subsection{Background of the Study}

Fischer, Halibozek, and Walters (2012) defined security as a predictable habitation where an individual or a group of people may achieve their dreams without fear of being disrupted, injured, or killed. From the above perspective, security can be associated with a sense of being free from fear of disruption, injury, or any deliberate activity that may disrupt one from attaining their goal. George and Kimber (2014) opine that it is difficult to define the concept of private security based on the existence of different variations in defining the term "security" itself, from which the idea of private security originates from. Nevertheless, several scholars have attempted to develop definitions for private security, even though most of them have provided definitions that suit their own perspectives and interests. Nsibambi (2014) defined "private security" as security and any related services being provided by any other entities apart from the government directed towards preventing crime.

Going back to the annals of history, Dempsey (2010) sheds light on the earliest documented circumstances in British England that necessitated the origin and the establishment of Private Security. The advent of this enterprise was catalyzed by increased crime in rural England in the early eighteenth century, which prompted the rich to recruit private individuals who mostly included gamekeepers to secure their properties on their behalf. They later formed security associations and established collaborations in a bid to gain more strength and resilience. These events took place even though there was a government that was in existence at that time. From then, the concept of Private security became the norm globally.

According to Nemeth (2012), the concept of Private security in continental America followed the same patterns as Medieval England. The need for the colonial settlers from England to protect themselves from threatening hostilities and attacks from the native red Indians and other colonial powers such as the Spanish resulted in the formation of watch groups. The first documented one dates back to 1634 in Boston. The need for 
security watch services made it mandatory for all males above 18 years to be enlisted in active night watch duties to ensure maximum security for the forts. Later on, this new trend in security took a commercialization trend with the formation of Pinkerton Company in Chicago by Allan Pinkerton, which later became the most prominent Private Security firm in the world.

Berg and Howell (2017) opine that South Africa provides the best trajectories for studying private security since they have the best experiences in implementing private security as a practice. They argue that the private security industry in South Africa grew rapidly between the 1970s and early 1980s due to anti-apartheid revolts since most policing efforts were directed towards quelling the revolts. There was increased crime and anarchy; thus, private security service providers had to be allowed to bridge this gap. Currently, many private security service providers are operating in the country. According to Kasali (2011), the consumption of services provided by Private security service providers is not considered a strange phenomenon in Nigeria. In the pre-Colonial Nigerian culture, the traditionally rich ancient times often required private guards' services to protect their households against physical attacks.

Kenya, as a developing country, enjoys a rich history of private security with the first private security companies, including KK Security (Currently known as Guard a world), Securicor Kenya (Currently operating as G4S), and factory guards (Currently operating as Security Group) being in existence in the country since the early 1960s before the country gained independence (Abrahamsen \& Williams, 2011).

\subsection{Statement of the Problem}

Despite the consistent presence and existence of state-provided law enforcement agencies, including the National Police Service, the County enforcement units and other quasi-police units, there has been an enormous increase in the presence and use of private security service providers in preventing crime and managing public safety in Lurambi Sub-County, Kenya. A keen review of most commercial, residential, and public spaces depicts private security service providers as the key players in crime prevention despite the presence of state law enforcement agencies who ought to provide such services as part of the social welfare services to which they are paid to provide. Karuri and Muna (2019) state that previous studies conducted in Kakamega County, including Lurambi-Sub County, have focused on law enforcement and community policing, deliberately omitting other relevant stakeholders, including private security service providers who are ever-present and persistently contributing to crime prevention. They also argue that previous studies have focused on specific security programs, including community policing and the Nyumba Kumi Initiative, leaving out the crime prevention aspect of them.

This necessitates more in-depth studies on private security service providers and their levels of training and how it impact on crime prevention in Lurambi Sub-County, Kenya.

\subsection{Research Objective}

To determine the training levels of private security service providers in crime prevention in Lurambi Sub-county, Kenya

\subsection{Research Questions}

What are the training levels of private security service providers in crime prevention?

\subsection{Significance of the Study}

This study is likely to provide more profound knowledge into private security service providers' activities and their contribution to crime prevention. The research evaluated the resources available for private security service providers and how they affect crime prevention, training levels of private security service providers, how it influences crime prevention, and the relationship between private security service providers and national security organs in crime prevention. On $18^{\text {th }}$ May 2016, President Uhuru Muigai Kenyatta ascended into law the Private Security Regulatory Act No 13 of 2016, which is geared towards regulating the private security industry. This provides the need for research in this industry that until recently was unregulated (Diphoorn, 2016). Existing research works on private security companies have previously been conducted in parts of Kenya, including Kikuyu Sub County (Anicent, 2014), Nairobi County (Githimi et al., 2017), and Bungoma County (Sikulu, 2014). The findings may go a long way in contributing knowledge to the existing research works on private security companies previously conducted in parts of Africa, Europe, and the USA. This research may help determine whether the existing previous research findings still hold over time and across regions. Policymakers in the security sector will utilize the findings of this research. Policymakers in the security industry may also utilize the findings to formulate policies informing decision-making.

\subsection{Literature Review}

This secvtion analyses this subject's existing literature by examining current studies sustaining or opposing this 
research.

\subsubsection{Introduction to security and private security}

According to George and Kimber (2014), there is no standard definition for the term "security" based on the fact that there are different variations in the same definition. However, several notable scholars in the field of safety and security have attempted to come up with different definitions in a variety of senses to bring about a variety of meanings. Fischer et al (2012) defined security as a predictable habitation where an individual or a group of people may achieve their dreams without fear of being disrupted, injured, or killed. From the above perspective, security can be associated with the physical aspect and the psychological sense. It is a combination of a good state of mind supported by a peaceful environment conducive to an individual to actualize their goals.

According to Franke and Von (2011), any act involving putting up deliberate measures to prevent a security or a criminal risk from happening qualifies to be referred to as crime prevention. This is based on the analogy that crime prevention is proactive rather than reactive. Franke and Von (2011) further opine that, even though the State may manifest itself as a monopolist in providing security and related services, they are not the only entities within the society involved in such a great course. The above statement indeed reaffirms that even though security may manifest itself through different perspectives, the government is not the only institution engaged in crime prevention and the provision of security-related services. It proves that security, just like many other activities, may also be commercialized or privatized.

According to Abrahamsen and Williams (2016), the commercialization of security, which was previously, a social welfare system funded by the State, has aroused a lot of interest worldwide in recent years. The debates on the use of private military contractors, also known as the dogs of war and mercenaries, have not escaped the public limelight. This has shaped the growth of private security industries. The statement above proves that the provision of security and related services was purely a State affair until recently. Private security is a new phenomenon that is taking shape in postmodern society.

Nsibambi (2014) defined "private security" as security services provided to clients by non-State agencies. He cited that the growth of private security in most parts of Africa has been propelled by governments' lack of sufficient capacity and funds to provide proper security to the citizens. He used South Africa and Uganda's case that he cited as a case study representing many other African countries ranked as the third world and struggling in funding the basic social welfare programs. From this approach, it can be deduced that any security and related services being offered by any other entity rather than the State qualified to be labelled as private security. This is based on the fact that the provision of security is considered one of the core functions and the characteristics of a government from the earliest eras of monarchs to the modern times when democracy is the order of the day.

George and Kimber (2014) argue that the concept of Private security existed much earlier than most of the global governments and empires. They argue that the first attempts of private security can be derived from the deliberate attempts and activities of early and less civilized individuals to protect their land and families from potential threatening dangers and hostilities. However, this narrative can be disputed because, at such a time, the concept of government had not yet existed. Thus, the institutionalization of security as one of the core functions of government was not yet realized. Going back to the annals of history, Dempsey (2010) sheds light on the earliest documented circumstances in British England that necessitated the origin and the establishment of Private Security. The advent of this enterprise was catalyzed by increased crime in rural England in the early eighteenth century, which prompted the rich to recruit private individuals who mostly included gamekeepers to secure their properties on their behalf. Simultaneously, the rich provided security back up to their guards by sleeping within the same establishment with their weapons ready to help repulse any form of threat, hostility, or even danger that might be lurking around. They later formed security associations and established collaborations in a bid to gain more strength and resilience. From my perspective, it is essential to note that a government was in existence during this period. However, the wealthy citizens took it upon themselves to provide security for their households and properties. The existing government did not take any part in this arrangement. From then, the concept of Private security became the norm globally.

According to Nemeth (2012), the concept of Private security in continental America followed the same patterns as Medieval England. The need for the colonial settlers from England to protect themselves from threatening hostilities and attacks from the native red Indians and other colonial powers such as the Spanish resulted in the formation of watch groups. The first documented one dates back to 1634 in Boston. The need for security watch services made it mandatory for all males above 18 years to be enlisted in active night watch duties to ensure maximum security for the forts. Later on, this new trend in security took a commercialization trend with the formation of Pinkerton Company in Chicago by Allan Pinkerton, which later became the most prominent Private Security firm in the world. Its growth was catalyzed by the claims that they protected Sir Abraham Lincoln from an assassination attempt.

According to Strom et al (2010), Private security industries are an essential component of security and safety in the United States and abroad today since private security is responsible not only for protecting many of the nation's institutions and critical infrastructures systems but also for protecting intellectual property and 
sensitive corporate information. From the above statement, it can be deduced that since the United States is one of the world's most developed countries, the fact that they have allowed private security to secure most of their critical infrastructure proves the fact that they have the capacity and the resources to prevent crime. In order for the State to trust private entities with critical infrastructure, the private sector has to prove to the State that they have the capacity and the resources needed to secure and maintain the infrastructure. This also applies to Kenya, where many key parastatals have contracted private security service providers to secure their facilities despite being state entities with the ability to request security directly from the government.

According to Abrahamsen and Leander (2016), the expansion of private security as a form of business has grown rapidly worldwide and in Africa. The same perspective is advanced by Gumedze (2010), who argues that South Africa provides the best trajectories for studying private security since they have the best experiences in implementing private security as a practice. According to Berg (2010), the private security industry in South Africa grew rapidly between the 1970s and early 1980s when the South African law public enforcement agencies diverted their attention from the primary policing duties to concentrate on quelling revolts that resulted from the anti-apartheid campaigns that were being advanced by the majority black. They had to do this to contain the high political temperatures as this period was the height of the heat of several anti-apartheid campaigns. To prevent further anarchy, the South African Apartheid government had no option but to allow the private security companies to bridge the gap. Currently, most private security service providers operating in the country possess relevant training, knowledge, skills, and experience in military science, intelligence gathering, criminology, and basic police training.

Kenya, as a developing country, enjoys a rich history of private security with the first private security companies, including KK Security (Currently known as Guard a world), Securicor Kenya (Currently operating as G4S), and factory guards (Currently operating as Security Group) being in existence in the country since the early 1960s before the country gained independence (Abrahamsen \& Williams, 2011). The above perspective proves that private security is not new or rather did not start with the economic recess in the early 1990s. Private Security Companies were in existence even before the country gained independence from the British in 1963.

However, Ngari (2015) notes that the exact number of private security service providers operating within the country cannot be established because there was little to no regulation of the industry since most private security companies were registered as private limited companies operate as such. However, through the Ministry of Interior and coordination of the National Government, the Government of Kenya has recently made great strides towards regulating the industry after President Uhuru Kenyatta signed the Private Security Regulatory act in May 2016. This is proof enough that the government is committed to implementing the recommendations of The United Nations Guidelines for the Prevention of Crime of 2010. The guidelines offered advisory that the State and the corporate sector should work together to prevent crime. In this sense, private security service providers are one of the key players in the corporate sector.

1.6.2 Training levels of Private Security Service Providers in Crime Prevention.

According to Button and Stiernstedt (2018), the notable conflict areas between Private Security Service Providers and State law enforcement agencies are their training levels. This has laid a foundation for the supremacy wars that have been prevalent in the security industry for a long time. Button and Stiernstedt (2018) further argue that state law enforcement agencies look down upon private security service providers on the basis that they are inadequately trained to meet the diverse demands of crime prevention. This argument holds some water because only a few multinational private security service providers own a proper training school in Kenya. Among them includes Group 4 Security, Wells Fargo Security, Kleen Homes security, among a few. Most firms in Kenya are unregulated and unregistered, operating more like vigilante groups rather than private security service providers.

This analogy has been supported by Kasali (2011), who argued that most Private Security Service Providers instead concentrate on flimsy aspects of training such as physical fitness at the expense of important aspects relating to crime prevention such as intelligence management, basic criminology, crowd control, riot management, information security management among many. This statement can be deduced to be true since most private security service providers do not own well-equipped training schools with facilities such as classrooms for theory lessons and fields for practical and physical training. It should be noted that most of them only undertake physical training at public amenities such as stadiums and playgrounds. Sometimes, the recruitment center may also double as a training facility. The training barely lasts a week before the new recruits are quickly dispatched to their first assignment. This renders them incapable of meeting the diverse demands for crime prevention, including aspects such as familiarity with the Private Security Regulatory Act 2016 and the basic aspects of crime prevention. Buzatu \& Buckland (2015) argue that two major aspects complicate the nature of private security service providers: the provision of security services, which was previously the State's role, and the delivery of the services by the non-State actors. Since security is a very sensitive matter to the extent that it was previously a preserve of the State, private security service providers have to be adequately trained to not only meet the rigorous demands of the industry and but also match the quality of the law enforcement agencies 
who are viewed by the public as the main face security and crime prevention. Simultaneously, the training ought to be dynamic and liberal in relation to the evolving nature of crime. As crime changes, so should the training. From the above statement, it can be deduced that training is an important aspect that will determine their output in crime prevention at any given time. It dictates the quality of the service that will be rendered at the end of the day. The same applies to the quality of the private security officers since it is the training that converts a civilian into a security officer.

\subsubsection{The United Nations recommendation on training levels for private security service providers}

According to Shaw (2010), the United Nations Guidelines for the Prevention of Crime of 2010 offers advisory that government institutions, all segments of civil society, and the corporate sector should work together to prevent crime. As indicated in the note by the Secretariat on Civilian private security services, these services have a role in crime prevention and community safety. This provides another basis for the formulation of an international legal framework for the regulation of the private security industry universally irrespective of the jurisdiction of operation. This partnership is not limited but may cover joint training areas and develop an internationally accepted training manual that may be used to standardize the training procedure and techniques. This may also regulate entry and exit into the profession by outlining the minimum qualifications needed for one to join this noble profession.

According to Conte (2017), the concept of "collective security "and "collective self-defence" have been mentioned numerously in the United Nations documents on security and international order. They form part and parcel of Chapter 7 of the United Nations charter. Even though the concept seeks to regulate affairs among States on international armed conflict matters, it mostly benefits civilians. It provides another avenue for collaboration among countries to formulate the legal framework for regulating private security service providers worldwide. This will facilitate common and standard training for private security service providers across the globe. This will significantly improve the quality of their services worldwide and, at the same time, increase their efficiency in crime prevention. According to Gumedze (2010), South Africa provides the best trajectories for studying private security in Africa since they have the best of experiences in implementing private security as a new practice in continental Africa. This may allow the less developed African countries to benchmark, gain skills, and create a quality training manual that may be used to regulate training in the industry in Africa and Kenya.

1.6.3 The regulatory framework and training levels of Private Security Service Providers in Crime Prevention

From the Kenyan perspective, the legal framework stipulated in the Private Security Regulatory Act of 2016 guides Private Security Service Providers' activities, including describing the nature and the extent of training for private security service providers across the country (Private Security Regulatory Act, 2016). This legal framework was formulated to ensure quality in terms of training and the overall regulation of the private security industry that was previously unregulated. According to the Private Security Regulatory Act (2016), legal notice no 108 on the private security regulatory act of 2016 mandates private security service providers to carry out vetting and background checks processes for prospective individuals wishing to be employed as a private security officer. Before employment, the requirements needed include proof of prior security training in a registered and authorized training school, accurate employment history, previous training, work experience, and at least three referees who must be contacted at the vetting stage.

This process is important because it ensures that an employer conducts thorough background checks on potential employees to ensure that they don't pose a threat to their clients and the members of the public. There have been reported incidents of private security officers engaging in crimes on assignments and projects they are paid to protect. This is ironic given that private security service providers are expected to be at the forefront of preventing and condemning crime. The media have hyped such cases to attract attention from the stakeholders, who include the state and clients alike (Dobson, 2019).

In Kenya, G4S, one of the largest security service providers, has experienced cases where employees working in the company's cash in transit department are suspected of having stolen more than 500 million between 2009 and 2010. The most recent case involved losing 40 million in Kenyan currency that a client had contracted them to transport from Kisumu to Busia (Kote, 2013). The Private Security Regulatory Act (2016) puts across a cautionary legal notice that any Private Security Service provider who shall not have a training facility shall provide proof of evidence to satisfy the existence of any partnerships or collaborations with a licensed training institution or preferably a security firm that offers the same training. Failure to adhere to this will lead to the revocation of their operating licenses. This regulation sheds on how seriously the aspect of training is to private security service providers. Good practice will significantly influence their role in preventing crime.

Section 2A of the act stipulates that a Private Security Service Provider must have a training facility within their administrative or rather head offices, which must be designed according to the Private Security Regulatory Authority's guidelines and layouts. Simultaneously, to make the training facilities more effective, private security service providers are required to employ a trainer who will be in charge of the training department and the 
facilities within the premises (Private Security Regulatory Act, 2016). The Regulatory Act provides a standard curriculum for training and assessments for private security training, which shall be mandatory and undertaken in every private security training institution across the jurisdiction.

\subsubsection{The influence of training levels for private security service providers on crime prevention}

The Private Security Regulatory Act (2016) puts across a cautionary legal notice that any Private Security Service provider who shall not have a training facility shall provide proof of evidence to satisfy the existence of any partnerships with a licensed training institution. Failure to adhere to this will lead to the revocation of their operating licenses. This regulation sheds on how seriously the aspect of training may influence crime prevention. Buzatu (2015) reviews the international regulatory frameworks that regulate the private security regulatory industry regarding training in the United Kingdom. The British government engaged in Public-Private partnerships with the Security in Complex Environments Group (SCEG), which operates within the Private security sector.

The partnerships aimed to provide oversight in controlling quality by imposing strict requirements in training, recruitment of personnel, and the nature of the firms' services. This has significantly improved the quality of training for private security service providers in the UK, both within and beyond the countries jurisdiction. This proves the fact that industry associations within the private security sector in Kenya such including Kenya Security Industry Association (KSIA), The Kenya National Private Security Workers Union (KNPSWU), and the Protective Security Industry Association may work together in collaboration with the private security regulatory authority to develop an industrial training manual that may be applicable throughout the country in line with the Private Security Regulatory Act 2016.

There have been reported incidents of private security officers engaging in crimes on assignments and projects they are paid to protect. This is ironic because private security service providers are expected to be at the forefront of preventing and condemning the crime. The media have hyped such cases to attract attention from the stakeholders, who include the State and clients alike (Ambogo, 2014). In Kenya, G4S alone are experiencing cases where employees working in the company's cash in transit department are suspected of having stolen more than 500 million between 2009 and 2010. The most recent case being reported where the company lost 40 million that a client had contracted them to transport from Kisumu to Busia (Ambogo, 2014).

From the above statements, it can be deduced that private security service providers are not adequately trained to handle the security market demands. Cash in transit is one of the complicated assignments that have been left at the disposal of private security service providers despite the fact that they are not armed and have to rely on the services of armed police officers to be part of the assignment.This incident proves the statement opined by Chinwokwu (2018) that private security are not adequately trained to meet industry demands. Instead, they have only been trained on flimsy aspects of security, such as access control and guarding at the expense of serious elements such as professional ethics, public relations and customer care, crime prevention, management, use of weapons, and cybercrime.

White (2012) argues that private security service providers have been legally empowered to perform quasipolicing duties such as arresting suspects, confiscating contraband goods, and even recording crime incidents into the police system in most developed nations. For them to be effective, they have to be trained in these relevant areas of expertise. From the above statement, it can be concluded that private security's traditional roles are changing to conform to the dynamic nature of policing's postmodern needs. Previously, they had been confined to traditional roles of physical security and access control duties. Thus, the change of roles calls for changes in training.

\subsubsection{Theoretical Framework}

Criminologists study how, why, when, where, and under what conditions crime, criminality, and victimization occur (Barlow \& Kauzlarich, 2010). The concept and role of private security in criminology are majorly established under Becker's famous Routine Activity Theory in 1976.

\subsubsection{Routine Activity theory (RAT)}

According to Felson and Boba (2010), Cohen and Felson were the first scholars to discuss the Routine Activity Theory in 1979, which explained the special circumstances required for a crime to happen. Later this theory was revised to suggest that for a criminal act to occur, three aspects must converge within the same space and time. The three aspects include a motivated offender, a suitable target or victim, and a potential guardian's absence. A motivated offender, in this case, may be anyone who may have any reason whatsoever to commit a crime. A suitable target might be any object worth stealing or a physical object that faces the risk of vandalism, or a person who faces the risk of victimization by the motivated offender. In this case, a potential Guardian might be any person whose presence may stop the crime incident from happening, including family members, police officers, neighbors, or Private Security Service Providers.

Schneider (2014) opined that potential guardians might also include Private Security Service Providers who may have the overall responsibility of controlling behavior within a specific location, such as a business establishment with authority from the client. Barlow and Kauzlarich (2010) argue that the availability of crime 
opportunities plays a significant role in crime causation. For example, one cannot rob a bank without a chance to do so, which in this case is the existence of a bank. A crime opportunity presents itself through the availability of suitable victims and targets. These crime opportunities are concentrated over time and space. They depend on everyday movements and activities.

According to Leclerc (2014), private security firms usually employ a number of ways to implement the routine activity theory. They include increasing the effort of committing a crime through target hardening by installing electric fences and alarms at a fee. Leclerc (2014) further states that private security service providers implement the theory by increasing the risk of getting caught by installing CCTV Cameras for clients and conducting both on-site and remote surveillance on the client's property and other security needs. The same is also achieved by implementing another defense line, such as baggage screening and natural surveillance using guards.

According to Leclerc (2014), removing excuses is another form of crime prevention advanced by this theory. Private security service providers attain this by attaching their labels to their client's property, e.g., manned by BM Security, under CCTV surveillance, and many others. This is done to announce their presence and psychologically prepare any potential offender that they might have to be vetted and approved before accessing the private property, the client, or the target they are seeking to gain from. Leclerc (2014) argues that private security service providers prevent crime by concealing the possible target by conducting covert operations in cases involving high valued targets such as cash in transit. They also apply target removal and property identification by creating an inventory of the property and clients who have contracted them to provide their services. This guides them in the decision-making process to recruit and allocate strength in their various posts and branches (Leclerc, 2014).

\subsubsection{Situational crime prevention theory}

Unlike other theories in criminology, situational crime prevention focuses on existing circumstances within the environment that make it possible for a crime to occur and then, using in-depth analysis, develops the mechanisms to mitigate these circumstances. The mechanisms are aimed at reducing the opportunities and the rewards of crime. Freilich and Newman (2017) further note that situational crime prevention is among the few theories that can be applied beyond the current criminal justice system to support corporate and personal security efforts. According to Newburn (2012), situational crime prevention is widely applicable in law enforcement practice, administration, and management. Situational crime prevention is used in problem-solving policing, one of the major strategies applicable to policing worldwide. It focuses on a specific crime problem and the development of proactive mechanisms to resolve this crime problem.

According to Huisman and Van (2013), situational crime prevention emerged 45 years ago through merging ideas from other notable theories, including rational choice and opportunity structure theories.

Gruenewald et al (2015) opine that situational crime prevention best achieves crime prevention because it targets situational factors, thus making it impossible for the criminal act to be actualized irrespective of the offender's motivation by eliminating any possible factors that may arouse the offender's interest.

Smith and Clarke (2012) outline the five crime prevention strategies advanced by Cornish and Clarke. Among them includes increasing the effort needed to commit crimes, increasing the risks of detection and getting arrested, reducing the rewards for committing crime, reducing provocations that lead to offending, and removing excuses for engaging in crime.

Smith and Clarke (2012) further allude that the risk of detection and getting arrested can be increased through extending guardianship on a property or a particular location which can be achieved physically through the use of private security service providers and electronically through the use of CCTV cameras which can be manned remotely by private security service providers. Others include natural surveillance, reducing anonymity cases within the physical environment, employing facility managers, and introducing electronic and remote surveillance. Clarke (2017) states that reducing the rewards of committing crime can be attained through concealing goods that may likely attract criminals, entirely removing them from plain view to reduce provocation, identifying properties through marking them and installing license plates on them. These activities can be undertaken by individuals or through contracting private security service providers who offer services, including engraving identity marks on properties, including tamperproof watermarks to protect brands against theft and concealment. Private security also does this by identifying and recovering stolen property.

Clarke (2017) further mentions reducing provocations as another strategy applicable in situational crime prevention. It includes individuals avoiding disputes, reducing provocation, neutralizing and repulsing negative peer pressure, and reducing imitation through brand protection efforts by private security companies dealing in brand protection and anti-counterfeit efforts. Clarke (2017) concludes by noting the removal of excuses as the fifth strategy; however, it can be achieved through strictly adhering to laws, rules, and regulations and adhering strictly to security and safety rules and procedures. The regulations, security policies, and safety guidelines can be publicized through posters and any other publications. 


\subsection{Research Methodology}

This study employed descriptive and correlational study research design. According to Creswell and Creswell (2017), the descriptive research design is commonly applied in studies that intend to describe and interpret the current status of individuals, settings, conditions, events, or a phenomenon as it exists within the society. The researcher has no intentions to manipulate the variables in order to influence the outcome. Creswell and Creswell (2017) further allude that descriptive studies are easier and simpler to conduct. They explain social phenomena as they naturally exist yet quite significantly provide a foundation upon which correlational and experimental studies emerge.

The study was carried out in Lurambi Sub-County of Kakamega County, Kenya. Lurambi Sub County hosts Kakamega town, which is the headquarters of Kakamega County. It is the second-largest county in Kenya (Wegulo, 2014). It is the regional headquarters of the larger Western Province. It lies 50 Kilometers North of Kisumu City at an altitude of 250-2000 meters. It has six wards, including Butsotso east, Butsotso south, Butsotso central, Shieywe, Mahiakalo, Shirere (Wegulo, 2014). It is an administrative, commercial, residential, industrial, and cosmopolitan set-up, making it prone to social problems such as crime (Wakhu, 2012).

The target population consisted of private security officers, managers, and clients drawn from regulated and registered private security firms operating in Lurambi Sub-County Kenya and senior police officers of the national police service each in charge of police stations spread across Lurambi Sub-County.

The accessible population included 18 private security firms operating in Lurambi Sub-County. Purposive sampling was used to identify 6 private security service providers who participated in the study on the premise that they were the only private security firms that were fully registered, licensed, and permitted to operate and thus more willing to participate in the study hence providing the study population. According to Creswell and Creswell (2017), purposive sampling is a form of sampling where individuals are selected to participate in research based on a specific purpose. In this case, the 6 private security service providers were the only firms fully registered and licensed to offer private security services.

The target population involved 358 private security officers drawn from the 6 firms. Proportionate sampling with a statistical framework of $30 \%$ was used to identify 108 private security service providers who formed the sample size to ensure that the private security officers from the 6 firms were represented in the same proportion that they existed within the population. According to Creswell and Creswell (2017), proportionate sampling is a sampling method in which the researcher divides a finite population into sub-populations and then applies random sampling techniques to each subpopulation. Creswell (2014) explains that a sample of $20-30 \%$ of the accessible population is adequate for purposes of generalization of findings from the sample onto the entire population from which the sample was obtained. Simple random sampling was applied to identify respondents from each of the six firms.

Being descriptive research, the study involved assessing attitudes, opinions, and responses of Private Security Service Providers towards crime prevention. The researcher obtained permission from the University's School of Post Graduate Studies, the National Council for Science Technology and Innovation (NACOSTI), the County Director of Education, and the Ministry of education to comply with the regulatory framework governing research. The descriptive data was collected using questionnaires and interview schedules. The questionnaires for private security officers, the branch managers, and the clients for private security officers comprised both open and closed questions, which were preferred to take care of the illiterate respondents and who questionnaires posed a challenge. Interview schedules were used on the 5 senior police officers in charge of 4 police stations across Lurambi Sub-County. The questionnaires were filled and returned to the researcher. The researcher gained more control over the administered interview; hence bias recording was eliminated by obtaining clarifications when questions were not clearly were answered. According to Bryman (2016), more than one research tool can be used in descriptive research.

Data obtained from the field was edited and cleaned to ensure accuracy, completeness, and comprehensibility and coded for ease of analysis. Study data were analyzed using both descriptive and inferential statistics with the aid of the Statistical Package for the Social Sciences (SPSS) version 23 for windows. Descriptive statistics was computed to summarise and explain data and was presented in the form of frequencies, percentages, and mean. Inferential statistics included the Pearson product-moment Correlation Coefficient to measure relationships between variables and regression analysis to determine influences between and among variables. Qualitative data derived from open-ended questions was thematically presented in narrative forms and tables.

\subsection{Study Findings}

The study targeted 159 respondents, with 108 being private security officers, 40 private security clients, and 05 senior police officers commanding 4 police stations in Lurambi Sub-County. Out of the 159 identified for sampling purposes, 136 respondents were achieved with 89 private security providers, 6 were managers for private security firm managers, 36 private security clients, and 5 Senior National Police Service Officers. They 
participated in the study and returned data collection instruments. This gave the study a response rate of $81.76 \%$. According to Creswell and Creswell (2017), a response rate of more than $70 \%$ is enough to generalize findings from a sample onto the entire population from which the sample was drawn.

The study respondents comprised $106(77.94 \%)$ male and $29(21.32 \%)$ female respondents. With regard to the different sample categories, $89(65.92 \%)$ of the respondents were private security service providers, $6(4.41 \%)$ were managers for private security firms managers, $36(26.47 \%)$ were private security service clients, and $5(3.67 \%)$ were senior police officers. Respondents were drawn from 6 private security companies, 25 business premises, 8 private residences, 3 learning institutions and, 3 police stations, all spread across Lurambi SubCounty.

1.8.1 Influence of Training levels of private security service providers on crime prevention

The study's second objective sought to determine the influence of training levels of private security service providers and the firm's managers for private security firms on crime prevention in Lurambi Sub-County. Study data relating to training levels of private security service providers and crime prevention were subject analyzed, and findings presented in table 1.

Table 1: Descriptive analysis for minimum academic requirements for Private Security Officers (Guards) to join their Firms

\begin{tabular}{lcc}
\hline Academic Qualification & Frequency & Percentage (\%) \\
\hline KCPE Certificate & 19 & 21.34 \\
KCSE Certificate & 55 & 61.79 \\
Certificate in Criminology & 6 & 6.74 \\
Diploma in Criminology & 5 & 5.61 \\
Degree and above & 3 & 3.38 \\
No minimum qualification required & 1 & 1.69 \\
Total & $\mathbf{8 9}$ & $\mathbf{1 0 0 . 0 \%}$ \\
\hline
\end{tabular}

Source: Research Data (2019)

Findings in Table 1 revealed that $21.34 \%$ responded that their firms required at least KCPE to be employed. This is considered as the lowest academic qualification for one to be employed as a private security service provider in Kenya based on the fact that at this level, an individual is considered literate and thus can be able to do the paperwork involved in private security. However, such employees cannot be subjected to specialized training, limiting their career progression and unique input in crime prevention. $61.79 \%$ of the firms required at least a KCSE certificate, one of the basic education requirements in Kenya. This is commendable because such professionals may pursue a specialized and professional certificate, diplomas, and degree courses in security and crime prevention, increasing their efficiency $\mathrm{n}$ crime prevention.

The findings in Table 1 revealed that $6.74 \%$ responded that their firms required at least a certificate in criminology and security studies, while $5.61 \%$ needed at least a college diploma. $3.38 \%$ required at least a Degree and above to join their firms. This is commendable because private security officers trained in criminology and security studies are more efficient in crime prevention; however, interestingly, $1.69 \%$ required no academic qualification to join them. This may adversely affect the quality of service offered by such private security service providers. At the same time, this locks them out of any training and, in most cases, makes it difficult for them to fill in the required paperwork in the course of their duties, thus negatively affecting crime prevention efforts.

Study data relating to training levels of private security service providers and crime prevention were subject analyzed, and findings presented in table 2.

Table 2: Descriptive analysis for Levels of training for private Security Officers (Guards)

\begin{tabular}{llll}
\hline & Training levels & Yes & No \\
\hline 1 & Availability of training department & $\mathbf{4 4}(\mathbf{4 9 . 4 3 )}$ & $\mathbf{4 5 ( 5 0 . 5 6 \% )}$ \\
2 & Pre-recruitment security training & $\mathbf{3 2}(35.95 \%)$ & $\mathbf{5 7}(\mathbf{6 4 . 0 4 \% )}$ \\
3 & $\begin{array}{l}\text { Post recruitment security training } \\
4\end{array}$ & $\mathbf{4 7}(\mathbf{5 2 . 8 0 \% )}$ & $\mathbf{4 2}(\mathbf{4 7 . 1 9 \% )}$ \\
& $\begin{array}{l}\text { Satisfaction with the quality of training offered and whether } \\
\text { the training assists in the course of their duties }\end{array}$ & $\mathbf{3 0}(\mathbf{3 3 . 7 0 \% )}$ & $\mathbf{5 9 ( 6 6 . 2 9 \% )}$ \\
& $\begin{array}{l}\text { Availability of refresher courses in their Firms } \\
\text { Total of } 89\end{array}$ & $\mathbf{1 9 ( 2 1 . 3 4 )}$ & $\mathbf{7 0 ( 7 8 . 6 5 \% )}$ \\
& & & $\mathbf{1 0 0 . 0 \%}$ \\
\hline
\end{tabular}

Study findings in table 2 reveal that $50.56 \%$ of the respondents did not have training departments in their firms. The availability of training departments plays a crucial role in determining the quality and the nature of service being offered by private security service providers. Trained private security service providers tend to understand the dynamic nature of crime and thus are more efficient in crime prevention than untrained officers. The study in table 2 also revealed that $64.04 \%$ of the interviewed private security service providers did not 
receive pre-recruitment security training, proving that most private security service providers are not adequately trained.

The study further revealed that $47.19 \%$ of the respondents did receive post-recruitment security training, which means that most private security service providers do not offer on-job training, which is very important in increasing the efficiency of private security service providers in crime prevention.

The study also revealed that $66.29 \%$ of those who participated in the study were not satisfied with their firms' level of training. This proves that private security service providers do not address the training needs and concerns of their employees. Job satisfaction is an important aspect, failure to be satisfied in the aspects of training may affect their performance, in turn affecting crime prevention efforts.

On the other hand, it was revealed based on the study findings that $49.43 \%$ of respondents had training departments, $35.95 \%$ had pre-recruitment security training, $52.80 \%$ had post-recruitment security training, while $33.70 \%$ were satisfied with the level of training offered by their firms. When asked to state what they thought should be done in terms of training to improve crime prevention, $81.3 \%$ of the study respondents believed that continuous and regular training programs in line with emerging security challenges would improve crime prevention. This is true based on the dynamic nature of crime as a social phenomenon. To prevent new and emerging forms of crime efficiently, private security service providers need to be trained from time to time.

Findings in Table 3 show descriptive analysis for responses to items on resource availability.

Table 3: Descriptive analysis for responses by private security officers on areas of training

\begin{tabular}{|c|c|c|c|}
\hline & Areas of training & Yes & No \\
\hline 1 & Basic Communication Skills & $38(42.69 \%)$ & $51(57.30 \%)$ \\
\hline 2 & Basic First Aid Skills & $2(2.24 \%)$ & $87(97.75 \%)$ \\
\hline 3 & Basic Intelligence Gathering Skills & $9(10.11 \%)$ & $80(89.88 \%)$ \\
\hline 4 & Basic Crime Detection Skills & $34(37.07 \%)$ & $56(61.79 \%)$ \\
\hline 5 & Basic Crime Prevention & $34(38.20 \%)$ & $40(62.92 \%)$ \\
\hline 6 & Basic Radio Skills & $22(24.71 \%)$ & $67(75.28 \%)$ \\
\hline 7 & Basic Customer Care Skills & $30(33.70 \%)$ & $59(66.29 \%)$ \\
\hline 8 & Basic weapon Detection Skills & $10(11.23 \%)$ & $79(88.76 \%)$ \\
\hline 9 & Basic fire Management Skills & $4(3.56 \%)$ & $85(95.50 \%)$ \\
\hline 10 & Basic Combat/Self-defense Skills & $70(78.65 \%)$ & $19(21.34 \%)$ \\
\hline 11 & Basic physical fitness Course & $88(98.87 \%)$ & $1(1.12 \%)$ \\
\hline 13 & $\begin{array}{c}\text { Introduction to Private Security Regulatory Act } 2016 \\
\text { Total } 89\end{array}$ & $\begin{array}{l}2(2.24 \%) \\
(100.0 \%)\end{array}$ & $87(97.75 \%)$ \\
\hline
\end{tabular}

Study findings in table 3 reveal that $57.30 \%$ were not trained on basic communication skills, which is an essential part and parcel of their daily activities based on the fact that private security, especially those working in public spaces, deal with a large number of people and therefore have to communicate effectively both to the members of the public, their clients and in some cases the law enforcement agencies. This limits their role in crime prevention. The study finding in table Study findings in table 3 further revealed that $97.75 \%$ of the private security service providers were not trained in Basic First Aid Skills, which is very important in case they encounter medical emergencies in the course of their duties. Lack of training in basic first aid limits their potential in handling cases of medical emergencies that are very common, especially in the course of dealing with violent crimes. This limits their role in crime prevention.

The study findings also revealed that $89.88 \%$ of the respondents were never trained on Basic intelligence Gathering skills, thus unable to collect, process, and even manage basic criminal intelligence in the course of their duties. Intelligence management is very important in the course of their duties because it may enable actors within the security sector to act proactively and prevent crimes. Lack of knowledge in this crucial area limits their performance in preventing crime.

The study also revealed that $61.79 \%$ were not trained on Basic Crime Detection skills which are is essential in the concept of crime prevention based on the fact that it enables private security service providers to detect cases of crime and the presence of criminals easily and thus act proactively towards preventing their occurrence. Lack of this knowledge limits their efficiency in crime prevention. The study further revealed that $75.28 \%$ were never trained on Basic Radio Skills, 66.29\% were never trained on Basic Customer Care Skills, which are essential skills used in communication among themselves and between them and their clients. This somehow negatively affects their efficiency in crime prevention.

The study further revealed that $88.76 \%$ of the respondents were not trained on basic Weapon Detection skills, which are very important and applied in access control management to ensure their clients' safety, security, and public safety when working within public spaces. Lack of this knowledge limits their efficiency in crime prevention. The study also revealed that $95.50 \%$ were not trained in fire management skills. This means that they may not be able to manage a fire incident in case it occurred at their place of assignment, thus unable to prevent crimes such as arson. The Study findings in table 4.13 further revealed that $97.75 \%$ have never been trained on 
the Private Security Regulatory Act 2016, which is the legal framework that regulates their operations and governs their conduct in the course of their duties. This limits their ability to act ethically and within the law and thus limits their capability in crime prevention.

\subsection{2: Findings from managers on Levels of training of Private Security Service Firms}

A descriptive analysis was conducted for items on private security service providers' training levels, and findings are presented in the following section. Managers were asked to state the basic academic requirements for Managing their firms and findings presented in table 4

Table 4: Descriptive analysis for Levels of education of Managers for Private Security Firms

\begin{tabular}{lcc}
\hline Academic Qualification & Frequency & Percentage (\%) \\
\hline Diploma & 3 & 50.0 \\
Bachelor's Degree & 2 & 33.3 \\
Post Graduate & 1 & 16.6 \\
Total & $\mathbf{6}$ & $\mathbf{1 0 0 . 0}$ \\
\hline
\end{tabular}

Study findings in table 4 reveal that $3(50.00 \%)$ of the respondents indicated that they possess a diploma which is insufficient to manage a fully-fledged private firm. This limits their capability to manage their firms' performance, which significantly has a negative effect on crime prevention. The study findings in table 4 also revealed that $(33.33 \%)$ indicated that they possessed a sufficient degree to manage a private security firm. This is commendable because it may significantly contribute to the efficiency of the private security firms in preventing crime. It is worth noting that 1(16.66) possessed a master's degree in business administration. This is commendable based on the fact that they may use their academic qualifications and experience to manage the security firms and at the same time adequately train and offer consultancy services to professionals within the private security sector thus, contributing positively towards crime prevention. This is because managers of private security firms perform overall decision-making on behalf of their firms. Their decisions may affect crime prevention efforts directly.

\subsection{3: findings from Managers on training levels of private security and crime prevention}

Findings in Table 5 show the descriptive analysis of responses by managers of PSSPs to items on levels of training on crime prevention.

Table 5: Descriptive analysis for responses by managers of PSSPs to items on the levels of training and crime prevention

\begin{tabular}{|c|c|c|c|}
\hline & Items on levels of training & Yes & No \\
\hline 1 & Do you have a training department in your Firm & $4(66.66 \%)$ & $2(33.33 \%)$ \\
\hline & Have you ever attended any Security Management Training Course & & \\
\hline 2 & & $2(33.33 \%)$ & $4(66.66 \%)$ \\
\hline \multirow[t]{2}{*}{3} & Do you have any refresher management Courses in your Firm? & $5(83.33 \%)$ & $1(16.66 \%)$ \\
\hline & Have you been trained in any of the following fields? & & \\
\hline 1 & Management course for PSSPs & $1(16.66 \%)$ & $5(83.33 \%)$ \\
\hline 2 & Basic Accounting & $5(83.33 \%)$ & $1(16.66 \%)$ \\
\hline 3 & Trainers Course & $3(50.00 \%)$ & $3(50.00 \%)$ \\
\hline 4 & Advanced Crime Prevention Skills & $2(33.33 \%)$ & $4(66.66 \%)$ \\
\hline 5 & Criminology & $1(16.66 \%)$ & $5(83.33 \%)$ \\
\hline 6 & Criminal Investigations & $1(16.66 \%)$ & $5(83.33 \%)$ \\
\hline 7 & Private Security Regulatory Act 2016 & $2(33.33 \%)$ & $4(66.66 \%)$ \\
\hline 8 & Organizational Behavior & $3(50 \%)$ & $3(50 \%)$ \\
\hline \multicolumn{2}{|c|}{ Total 6} & $(100.0 \%)$ & \\
\hline
\end{tabular}

Study findings in table 5 by Private Security Firm Managers reveal that $33.33 \%$ of the PSSPs operating in Lurambi Sub-County do not have a training department. This contravenes the guidelines provided by the Private security regulatory act 2016, which dictates that all private security service providers operating within the country must have a training department within their administrative offices and must employ a qualified training officer to be in charge of training. Study findings in table 5 further revealed that $66.66 \%$ of the Private security firm managers have never attended a security management course despite being at the helm of the organization offering security and related services. This limits their management capacity to propel the performance of their firms towards crime prevention. 
Study findings in table 5 also revealed that $83.33 \%$ have never attended any private security firm management course. Thus this means they lack the managerial skills necessary to manage private security firms to attain crime prevention. The findings further revealed that $66.66 \%$ of the managers who participated in the study have never attended any Advanced Crime Prevention Skills course, which means that they lack the necessary knowledge and skills in crime prevention, thus inefficient in implementing crime prevention programs. The findings further revealed that $83.33 \%$ of the managers who participated in the study have never attended any course on criminology and criminal investigations, which is very important in facilitating knowledge and skills in crime prevention, while $66.66 \%$ have never attended any course on Private Security Regulatory Act (2016) which means that, they lack knowledge on the legal framework that governs private security service which supports their role in crime prevention. This is alarming since they are managing key entities in crime prevention and thus must possess at least basic relevant knowledge in relation to crime prevention.

However, the findings also revealed that $66.66 \%$ have a training department in their firms which means that they efficiently recruit and train their security officers to increase their capacity in crime prevention, while $83.33 \%$ have refresher courses in their firms. At the same time, $83.33 \%$ have attended courses on basic accounting, which is part and parcel of their duties to ensure efficient and effective management of resources to attain crime prevention. In comparison, $50 \%$ of the managers who participated in the study have attended trainer's course, which is essential to enable them to offer training services within their security firms, thus increasing the capacity of their firms in crime prevention. At the same time, $50 \%$ of the managers who participated in the study have been trained on organizational behaviour, which is an essential concept in managing private security firms. This is commendable since it has enabled them to assume the overall responsibility of managing these organizations, which are key stakeholders in crime prevention. The managers were also asked on what they think should be done in terms of training to improve on crime prevention, and they recommended factors such as reduced taxations, sharing of training facilities, the establishment of a national training school for PSSPs, and the development of a standard training manual for private security service providers nationwide.

1.8.4: Responses by clients on Levels of training for Private Security Service Providers

The table 6 below shows the findings for responses by clients on the levels of training for private security service providers on crime prevention in Lurambi Sub-County.

Table 6: Descriptive findings for responses by clients of PSSPs to items on the levels of training and crime prevention

\begin{tabular}{|c|c|c|c|}
\hline & Items on training & Yes & No \\
\hline 1 & Do PSSPs are adequately trained in crime prevention & $16(44.44 \%)$ & $26(72.22 \%)$ \\
\hline 2 & Does your contracted PSSP ever issue training updates? & $1(2.77 \%)$ & $35(97.22 \%)$ \\
\hline 3 & $\begin{array}{l}\text { Has your Contracted PSSP ever recalled an officer for training } \\
\text { Do you think PSSPs have been adequately trained to meet your }\end{array}$ & $1(2.77 \%)$ & $35(97.22 \%)$ \\
\hline 4 & security needs as a client? & $6(16.66 \%)$ & $30(83.33 \%)$ \\
\hline & Total & \multicolumn{2}{|c|}{$06(100.0 \%)$} \\
\hline
\end{tabular}

Study findings in table 6 by clients who have contracted PSSPSs reveal that $72.22 \%$ of the clients feel that PSSPs are not adequately trained in crime prevention. This may affect them having a negative perception on the capabilities of private security service providers in preventing crime, $97.22 \%$ of the clients who participated in the study have never been issued with training updates, this again results in a negative perception on the capabilities of private security service providers in preventing crime. The study findings in table 6 also established that $97.22 \%$ of the clients who participated in the study stated that the firms they have contracted have never recalled an officer from the client's assignment for training. This proves the fact that most private security service providers do not offer refresher courses for their clients, thus affecting their capability on crime prevention.

The study findings in table 6 also established that $83.33 \%$ of the clients feel that the PSSPs have not been adequately trained to suit their specific security needs. These findings reveal that PSSPs are not adequately trained, which may negatively influence their crime prevention levels. Most clients recommended that PSSPs be trained in critical areas such as public relations, Criminal Surveillance, Management, and firearms, and First Aid to enable them to deal effectively with a series of security and medical emergencies that may occur in their duties. Training in these critical areas may also bolster their efforts in crime prevention.

1.8.5: Quantitative findings for interviews with senior police officers on levels of training for private service providers and crime prevention.

Based on the interviews conducted between the researcher and the officers in charge of the four police stations in Lurambi Sub-County, $5(100 \%)$ of the officers interviewed believed that private security service providers are not adequately trained in crime prevention. At the same time, $4(80 \%)$ of those interviewed argued that private 
security service most providers who operated in Lurambi Sub-County do have a training department. These results adversely affect the quality of training, limiting their capability in crime prevention. The study further revealed that $4(80 \%)$ of the senior police officers interviewed have never been invited to attend or offer any training by private security service providers operating in Lurambi Sub-County. This proves the fact that most private security service providers do not provide any forms of training involving police officers, which is essential in fostering diversity of knowledge in crime prevention. Simultaneously, $5(100 \%)$ of the senior police officers in charge of 4 police stations across Lurambi Sub-County believe that refresher courses are essential for private security service providers.

"Some Private security firms quickly recruit officers and do not take time and invest resources to train them adequately. Sometimes we go out of our way as a service to offer training on matters relating to terrorism and intelligence gathering. This is because we view them more as stakeholders and partners in crime prevention rather than competitors.

I look forward to future collaborations in areas of training, development, and consultancies from PSSPs. As the National Police service, we look forward to working as a team towards a common goal, which is to prevent crime," Opined the officer in Charge of Kakamega Central Police Station (Field, 2019).

The officer in charge of the Kakamega Central police station stated that private security service providers are not adequately trained in crime prevention. "Most private security service providers train up to one week before being dispatched to their assignments. This period is not sufficient for a person to be able to cover all the relevant areas of law enforcement and private policing. This greatly undermines their efficiency in crime prevention". She stated. When asked whether most private security service providers in Lurambi Sub-County have a training facility, she responded that most of them do not have training facilities and most of the time use school playgrounds as a temporary training facility which limits their focus to physical fitness at the expense on many other concepts in crime prevention. She stated that she was once invited by one of the private security service providers to participate in the training program only to be surprised that it was being conducted on a field. Both trainers and trainees lacked the appropriate gear required for such training. This speaks volumes about the quality of training offered by the private security service providers in Lurambi Sub-County. The training did not address any aspects of collaboration with the law enforcement agencies to strengthen their capability in crime prevention (Field, 2019).

The officer commanding the Lurambi Police post stated that most private security service providers are rarely trained by their employers. They are simply given one pair of uniforms and instructed where to report. This limits their capacity to prevent crime and even collaborate with state agencies such as the police in crime prevention. "I have never been invited by any private security service providers for a joint training or to offer training to them. In most cases, I'm only contacted after a crime has happened to advise on how to go about investigations. Most firms here are more reactive than proactive towards crime. This is caused by a lack of proper training on crime prevention. The training should focus more on crime prevention rather than reaction". Said the officer in charge of the Lurambi police post (Field, 2019).

The Officer in Charge of the Ejinja Corner police post stated that most private security service providers hardly train their staff. "Most of them recruit staff after being contracted and hence have little or no time to offer training. In most cases, the private security officers have to learn on the job, limiting their capacity to prevent crime. It is even worse when the guard is illiterate or semi-illiterate. This limits their communication with the firm, law enforcement, and even clients, making them more vulnerable to manipulation by their employers, clients, and even criminals". Stated the officer in charge of Ejinja corner police post (Field, 2019).

When asked about the levels of training for private security service providers, the officer in Charge of Shirere police post stated that most private security service providers do not budget for training. "Most of them fear spending in order to reduce the operational costs and to maximize profits. This adversely affects their output while in the course of their duties and negatively affects crime prevention through increasing the fear of crimes among clients who consume their services." Stated the officer in Charge of Shirere police post. He concluded that most he has never been offered an opportunity by private security service providers to train them. He noted that he welcomes such a move since it will encourage collaboration between the two entities. He recommended that the National Government, in partnership with the private sector, should set up training schools and facilities for private security service providers in every region. This would improve the quality of training and facilitate the accessibility of training facilities and equipment. This would also encourage collaboration between the government and the private sector in preventing crime (Field, 2019).

"Training is one of the factors that determine the quality of a security officer. Private security service providers should be adequately in several areas, including crime prevention, access control management, lawful arrest procedures, and communication. This will help them gain the necessary skills needed to survive in the industry and collaborate with state law enforcement agencies. Otherwise, private security service providers in Lurambi Sub-County are not adequately trained. I have never been invited for any joint training or even pass out “. Stated the Lurambi Sub-County police commander when asked about the status training in relation to private 
security service providers in Lurambi Sub-County (Field, 2019).

1.8.6 Correlation results for levels of training for private security service providers and crime prevention Correlation Analysis between levels of training and crime prevention in Lurambi Sub-County was conducted, and findings in table 7 obtained:

Table 7: Correlations analysis for levels of training and crime prevention

\begin{tabular}{llll}
\hline & & Training Level & Crime Prevention \\
\hline Training Level & Pearson Correlation & 1 & \\
& Sig. (2-tailed) & .000 & \\
& $\mathrm{~N}$ & 136 & 1 \\
Crime Prevention & Pearson Correlation & $.594^{* *}$ & 136 \\
& Sig. (2-tailed) & .000 & 136 \\
& $\mathrm{~N}$ & 136 & \\
&
\end{tabular}

**. Correlation is significant at the 0.05 level (2-tailed).

A correlation coefficient statistic that describes the degree of linear association between training levels for private security service providers and crime prevention was conducted. Study findings indicated that a statistically significant and positive relationship between levels of training and crime prevention in Lurambi SubCounty $(\mathrm{r}=.594 ; \mathrm{P}<0.05)$. The statistical implication of this finding is that an increase in training results in an increase in crime prevention ability among private security service providers. These results conform to previous studies done by other scholars who concluded that levels of training for private security service providers improve on crime prevention ability.

This study conforms to the findings by Oanda (2013), who argues that most private security service providers operating in Kenya are not adequately trained; thus, this affects their efficiency in crime prevention. From the author's perspective, the quality of training offered to private security service providers contributes significantly to their levels of crime prevention, and thus, training is an essential element in the management and operations of private security service providers. Section 2A of the act stipulates that a Private Security Service Provider must have a well-equipped training facility within the administrative offices designed in the guidelines and layouts recommended by the Private Security Regulatory Act 2016. (Private Security Regulatory Act, 2016).

This study also conforms to the findings by Kasali (2011), who argued that most Private Security Service Providers only concentrate on flimsy aspects of training such as physical fitness at the expense of important aspects relating to crime prevention, which includes intelligence management, basic criminology, crowd control, riot management, information security management among many other important aspects of training. Based on the above statement, this can be deduced to be true since most private security service providers do not own well-equipped training schools with classrooms for theory lessons and fields for practical training. It should be noted that most of them only undertake physical training at public amenities such as stadiums and playgrounds. Sometimes, the recruitment center may also double as a training facility. The training barely lasts a week before the new recruits are quickly dispatched to their first assignment. This renders them incapable of meeting the diverse demands for crime prevention, which may include aspects such as familiarity with Private Security Regulatory Act 2016, basic knowledge in criminology, criminal intelligence, and surveillance, among many others. Among the requirements needed before employment includes proof of prior security training, accurate employment history to ascertain previous training and work experience, and at least three referees must be contacted in the course of the vetting process (Private Security Regulatory Act, 2016). Buzatu (2015) argues that two major aspects complicate the nature of private security service providers: the provision of security services, which was previously the State's role, and the delivery of the services by the non-state actors. Since security is a very sensitive matter to the extent that it was previously a preserve of the State, private security service providers must be adequately trained to meet the industry's rigorous demands. Simultaneously, the training ought to be dynamic and liberal in relation to the evolving nature of crime. As crime changes, so should the training. From the above statement, it can be deduced that training is an important aspect that will determine the output crime prevention at any given time. It dictates the quality of the service that will be rendered at the end of the day. The same applies to the quality of the private security officer since it is the training that converts a civilian into a security officer. This proves that there exists a significant relationship between the levels of training for private security service providers and crime prevention.

The results for regression analysis with training levels as predictors for crime prevention were undertaken, and findings are presented in table 8 . 
Table 8: Model Summary for Levels of Training and Crime Prevention

\begin{tabular}{llllll}
\hline & & & & Std. Error of \\
Model & $\mathrm{R}$ & R Square & Adjusted R Square & Estimate & Durbin-Watson \\
\hline 1 & $.323^{\mathrm{a}}$ & .231 & .228 & .86210 & 1.842 \\
\hline
\end{tabular}

a. Predictors: (Constant), Training levels

b. Dependent Variable: Crime Prevention

Source: Research Data (2019)

From table 8 , the value of $\mathrm{R}$ squared was 0.231 which shows that the training level explains $23.1 \%$ of the variance in crime prevention in Lurambi Sub-County. The remaining 76.9\% unexplained variance is largely due to other factors that influence crime prevention that are not included in the model.

Table 9: ANOVA for results for Levels of Training and Crime Prevention

\begin{tabular}{lllllll}
\hline Model & & Sum of Squares & Df & Mean Square & F & Sig. \\
\hline 1 & Regression & 25.799 & 1 & 25.799 & 34.712 & $.000^{\text {a }}$ \\
& Residual & 220.737 & 297 & .743 & & \\
& Total & 246.536 & 298 & & & \\
\end{tabular}

a. Predictors: (Constant), Level of Training

b. Dependent Variable: Crime Prevention

ANOVA for the linear model presented in Table 9 for training levels and crime prevention Authoritative has an $\mathrm{F}$ value $=34.712$, which is significant at $99 \%$ confidence level with $\mathrm{p}$-value $=0.000$, meaning that the overall model is significant in the prediction of crime prevention by private security service providers in Lurambi Sub-County. The study, therefore, shows that training levels have a statistically significant influence on crime prevention.

\subsection{Conclusion}

Based on the empirical evidence, it is concluded that there is a statistically significant and positive relationship between levels of training for private security service providers and crime prevention in Lurambi Sub-County. In line with this finding, it is concluded that levels of training for private security service providers influence crime prevention in Lurambi Sub-County.

\subsection{Recommendations}

With respect to the study findings and conclusions, it is recommended that through the Private Security Regulatory Authority, the state should enhance the provision of relevant and timely training programs by establishing The National Private Security Training Academy. This will enable private security service providers to access quality and standard training for their staff. This will also enable the state to control the quality and nature of training, therefore enhancing private security service providers' capacity to prevent crime.

\section{REFERENCES}

Abrahamsen, R., \& Leander, A. (Eds.). (2016). Routledge handbook of private security studies. Routledge, Taylor \& Francis Group.

Abrahamsen, R., \& Williams, M. C. (2010). Security beyond the state: Private security in international politics. Cambridge University Press.

Abrahamsen, R., \& Williams, M. C. (2011). Security privatization and global security assemblages. The Brown Journal of World Affairs, 18(1), 171-180.

Argote, L. (2012). Organizational learning: Creating, retaining, and transferring knowledge. Springer Science \& Business Media.

Barlow, H. D., \& Kauzlarich, D. (2010). Explaining crime: A primer in criminological theory. Rowman \& Littlefield.

Button, M., \& Stiernstedt, P. (2018). Comparing private security regulation in the European Union. Policing and Society, 28(4), 398-414.

Buzatu, A. M. (2015). Towards an International Code of Conduct for Private Security Providers (p. 61). Ubiquity Press.

Buzatu, A. M., \& Buckland, B. S. (2015). Private military \& security companies: Future challenges in security governance. Geneva Centre for the Democratic Control of Armed Forces.

Carmola, K. (2010). Private Security Contractors and New Wars: Risk, Law, and Ethics. Routledge.

Chinwokwu, E. C. (2018). An assessment of the relationship between private security companies and police crime prevention in Lagos Metropolis, Nigeria. International Journal of Police Science \& Management, 20(1), 80-93.

Clarke, R. (2017). Situational Crime Prevention: Theoretical Background and Current Practice. In D. Simpson, V. Jensen \& A. Rubing (Ed.), The City between Freedom and Security (pp. 84-113). Berlin, Boston: 
Birkhäuser.

Creswell, J. W. (2014). A concise introduction to mixed methods research. SAGE publications.

Creswell, J. W., \& Creswell, J. D. (2017). Research design: Qualitative, quantitative, and mixed methods approaches. Sage publications.

Cyber Crime Act 2018 Kenya Gazette

Dambazau, A., \& Rtd, L. G. (2013). Overcoming Nigeria's security challenges. Lecture given at the Eleventh Convocation Ceremonies of Igbinedion University, Okada, Nigeria, 28.

David, A. W. (2011). International Code of Conduct for Private Security Service Providers. International Legal Materials, 50(1), 89-104.

Dempsey, J. S. (2010). Introduction to private security. Belmont, CA: Wadsworth Cengage Learning.

Diphoorn, T. (2016). "Surveillance of the Surveillers": Regulation of the Private Security Industry in South Africa and Kenya. African studies review, 59(2), 161-182.

Dobson, N. (2019). Private Security in Nairobi, Kenya: Securitized Landscapes, Crosscurrents, and New Forms of Sociality. African Studies Review, 62(2), 30-48.

Drost, E. A. (2011). Validity and reliability in social science research. Education Research and perspectives, $38(1), 105-123$.

Eichler, M. (Ed.). (2015). Gender and private security in global politics. Oxford University Press, USA.

George, B., \& Kimber, S. (2014). The history of private security and its impact on the modern security sector. In The Handbook of Security (pp. 21-40). Palgrave Macmillan, London.

Gill, M. (2015). Senior police officers' perspectives on private security: sceptics, pragmatists and embracers. Policing and society, 25(3), 276-293.

Githimi, S., Bor, E., \& Appolos, M. (2017). How the availability of private security services assist in crime control in Nairobi County, Kenya. Global Journal of Arts, Humanities and Social Sciences, 5(1), 51-61.

Heap, V., \& Waters, J. (2019). Mixed methods in criminology. Routledge.

Hollis-Peel, M. E., Reynald, D. M., Van Bavel, M., Elffers, H., \& Welsh, B. C. (2011). Guardianship for crime prevention: A critical review of the literature. Crime, law and social change, 56(1), 53-70.

Huisman, W., \& Van Erp, J. (2013). Opportunities for environmental crime: A test of situational crime prevention theory. British Journal of Criminology, 53(6), 1178-1200.

Karuri, J. G., \& Muna, W. (2019). Effects of community policing on crime prevention in Kakamega County, Kenya. International Academic Journal of Law and Society, 1(2), 312-327.

Kasali, M. A. (2011). Analyzing the Evolution of Private Security Guards and their Limitations to Security Management in Nigeria. African Journal of Criminology \& Justice Studies, 5.

Kaweesi, A. F. (2011). The Relationship between Public and Private Security Providers: An Analysis of the Regulation of Private Security Providers in Uganda (Doctoral dissertation, University of Nairobi).

Kote, L. D. (2013). The Role Of Social Media In Crisis Communication In Security Firms In Kenya A Case Study Of G4s Kenya Limited (Doctoral dissertation, University of Nairobi).

Kothari, C. (2017). research methodology methods and techniques by CR Kothari. Published by New Age International (P) Ltd., Publishers, 91.

Krahmann, E. (2017). Legitimizing private actors in global governance: From performance to performativity. Politics and Governance, 5(1), 54-62.

Maxfield, M. G. (2015). Basics of research methods for criminal justice and criminology. Cengage Learning.

Miles, M. B., Huberman, A. M., \& Saldana, J. (2014). Qualitative data analysis: A methods sourcebook.

Mkilindi, A. M. (2014). Assessment of the role of private security Companies in the enhancement of public Security: the case of Ultimate security company in Kinondoni Municipal council (Doctoral dissertation, Mzumbe University).

Mugenda, A. G., \& Mugenda, A. G. (2012). Research methods dictionary. Nairobi, Kenya: Applied Research \& Training Services.

Newburn, T. (2012). The future of policing. In Handbook of policing (pp. 852-868). Willan.

Ngari, A. W. (2015). Mergers and Acquisitions as a Growth Strategy in the Private Security Industry in Kenya (Doctoral dissertation, United States International University-Africa).

Schneider, S. (2014). Crime prevention: Theory and practice. CRC Press.

Shaw, M. (2010). Handbook on the crime prevention guidelines: Making them work. United Nations Publications.

Smith, M. J., \& Clarke, R. V. (2012). Situational crime prevention: Classifying techniques using "good enough" theory. The Oxford handbook of crime prevention, 291-315.

Wegulo, B. (2014). Factors influencing service delivery on CDF managed projects in Kakamega sub county: Lurambi constituency (Doctoral dissertation).

White, A. (2014). Post-crisis policing and public-private partnerships: The case of Lincolnshire Police and G4S. British journal of criminology, 54(6), 1002-1022. 
Williams, M., \& Vogt, W. P. (2011). The SAGE handbook of innovation in social research methods. Sage Publications.

Wilson, J. Q., \& Petersilia, J. (Eds.). (2010). Crime and public policy. Oxford University Press. 